2. To: (Receiving Organization) Distribution

5. Proj./Prog./Dept./Div.:

W-519/TWRS Priv. Phase I

Infrastructure Support

8. Originator Remarks:

Inter-Project Interface Control Document for Project $\mathbf{W} 519$.

Identifies interfaces with Projects $W-314, W-464, W-465$, and W-520.

11. Receiver Remarks:
3. From: (originating organization)

R. J. Parazin / NHC Engr.:

N/A / N/A / D. Fort (FDNW)
6. Design Authority/ Design Agent/Cog.
4. Related EOT No.:

N/A

7. Purchase Order No.:

N/A

9. Equip./Component Ho.:

$\mathrm{N} / \mathrm{A}$

10. System/Bldg./Facility: 200-E

12. Major Assm. Ditg. No.: $N / A$

13. Permit/Permit Application No.: N/A

14. Required Response Date:

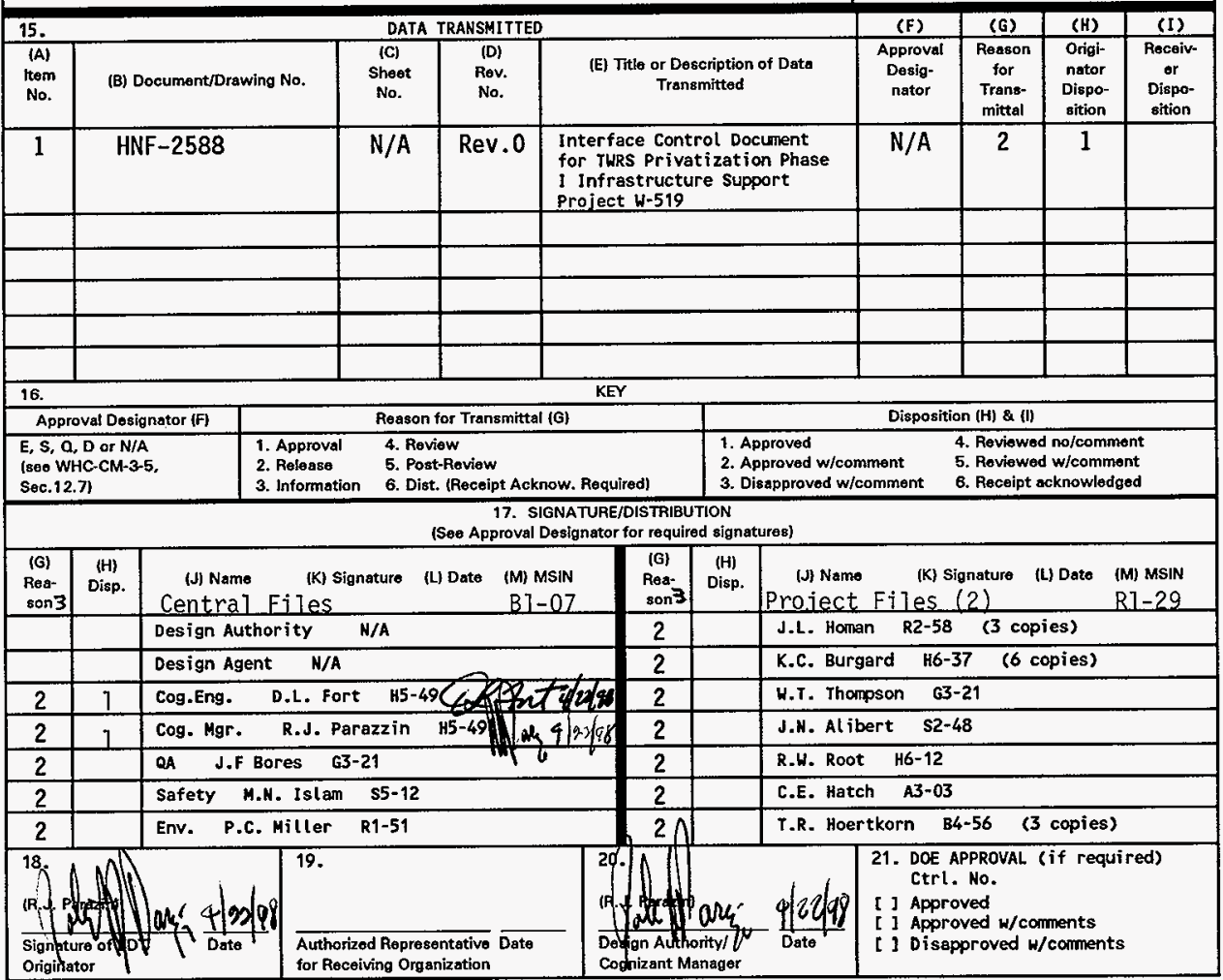

BD-7400-172-2 (05/96) GEF097 


\section{Interface Control Document for Tank Waste Remediation System Privatization Phase I Infrastructure Support Project W-519}

R. J. Parazin

Numatec Hanford Corporation, Richland, WA 99352

U.S. Department of Energy Contract DE-AC06-96RL13200

D. L. Fort

Fiuor Daniel Northwest, Inc., Richland, WA 99352

U.S. Department of Energy Contract DE-AC06-96RL13200

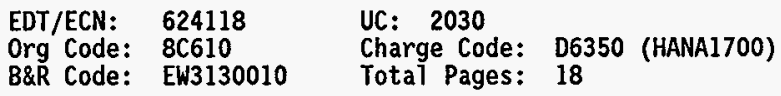

Key Words: Interface Control Document, Tank Waste Remediation System, TWRS, Privatization Phase I, Infrastructure Support, Project W-519

Project W-314, Project W-464, Project W-465, Project W-520

Abstract: This document describes the functional and physical

interfaces between the Tank Waste Remediation System (TWRS)

Privatization Phase I Infrastructure Project W-519 and the various other projects (i.e., Projects $W-314, W-464, W-465$, and $W-520$ ) supporting Phase I that will require the allocation of 1 and in and about the Privatization Phase I Site and/or interface with the utilities extended by Project W-519.

TRADEMARK DISCLAIMER. Reference herein to any specific comercial product, process, or service by trade name, trademark, manufacturer, or otherwise, does not necessarily constitute or imply its endorsement, recamendation, or favoring by the United states Goverrment or any agency thereof or its contractors or subcontractors.

Printed in the United States of America. To obtain copies of this document, contact: WHC/BCS Document Control Services, P.0. Box 1970, Mailstop H6-08, Richland Ha 99352, Phone (509) 372-2420: Fax (509) 376-4989.

$\frac{\text { Ravis } 2 \text { Reralad } 4-23-98}{\text { Date }}$

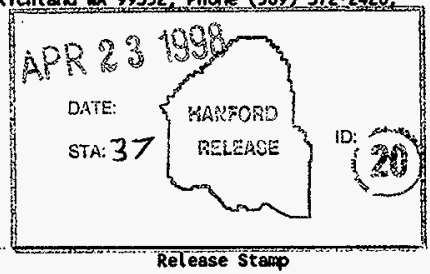


HNF-2588, Rev. 0

\section{INTERFACE CONTROL DOCUMENT}

for

\section{TANK WASTE REMEDIATION SYSTEM \\ PRIVATIZATION PHASE I \\ INFRASTRUCTURE SUPPORT \\ PROJECT W-519}

Numatec Hanford Company

Richland, Washington

April, 1998

Project Hanford Management Contractor for the

U.S. Department of Energy under Contract DE-AC06-96RL13200 
HNF-2588, Rev. 0

\section{INTERFACE CONTROL DOCUMENT}

for

TANK WASTE REMEDIATION SYSTEM

PRIVATIZATION PHASE I

INFRASTRUCTURE SUPPORT

PROJECT W-519

Numatec Hanford Company

Richland, Washington

Prepared by:

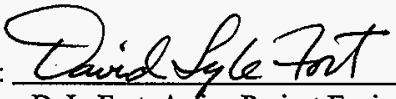

D. L. Fort, Acting Project Engineer (FDNW)
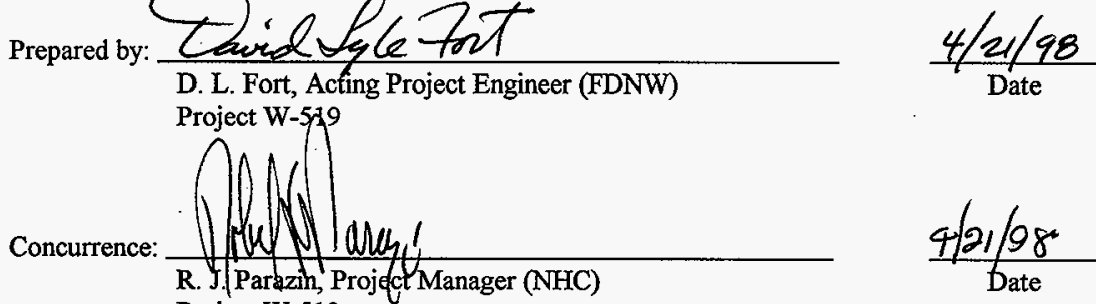

\section{Project W-519}

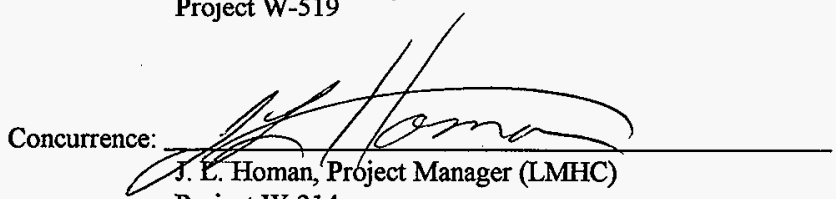

Project W-314

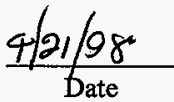

Concurrence: TOBunqued

K. C. Burgard, Project Manager (LMHC)

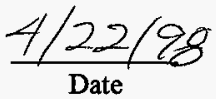

Projects W-464, W-465, and W-520

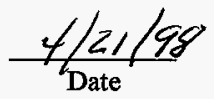


HNF-2588, Rev. 0

\title{
INTERFACE CONTROL DOCUMENT
}

\author{
FOR
}

\section{PROJECT W-519}

\subsection{Scope}

This document describes the functional and physical interfaces between the Tank Waste Remediation System (TWRS) Privatization Phase I Infrastructure Project W-519 and the various other projects supporting Phase $I$ that will require the allocation of land in and about the Privatization Phase I Site and/or interface with the utilities extended by Project W-519.

Project W-519 will identify land use allocations and upgrade/extend several utilities in the 200-East Area into the Privatization Phase I Site (formerly the Grout Disposal Compound) in preparation for the Privatization Contractors (PC) to construct treatment facilities. The project will upgrade/extend: Roads, Electrical Power, Raw Water (for process and fire suppression), Potable Water, and Liquid Effluent collection. The replacement of an existing Sanitary Sewage treatment system that may be displaced by Phase I site preparation activities may also be included.

The Projects interfacing with Project W-519 are:

$$
\begin{aligned}
& \text { W-314 - Tank Farm Restoration and Safe Operations } \\
& \text { W-464 - Immobilized High Level Waste Interim Storage Facility } \\
& \text { W-465 - Immobilized Low Activity Waste Interim Storage Facility } \\
& \text { W-520 - Immobilized Low Activity Waste Disposal Facility }
\end{aligned}
$$

The main elements and responsibilities that require interfacing and coordination between the various projects are listed in Table 1. 
HNF-2588, Rev. 0

\begin{tabular}{|c|c|c|c|c|}
\hline Project W-519 & Project W-465 & Project W-314 & Project W-464 & Project W-520 \\
\hline $\begin{array}{l}\text { 1. Prepare Phase I site } \\
\text { and utility corridors } \\
\text { for } P C(s) \text {. }\end{array}$ & $\begin{array}{l}\text { 1. Provide interim } \\
\text { storage with } \\
\text { possible disposal of } \\
\text { LAW. }\end{array}$ & $\begin{array}{l}\text { 1. Upgrade I\&C, tank } \\
\text { ventilation electrical } \\
\text { distribution, and } \\
\text { waste transfer } \\
\text { systems for existing } \\
\text { mixed waste tank } \\
\text { farm facilities at } \\
\text { Hanford. }\end{array}$ & $\begin{array}{l}\text { 1. Provide interim } \\
\text { storage for IHLW. }\end{array}$ & $\begin{array}{l}\text { 1. Provide for } \\
\text { disposal of ILAW. }\end{array}$ \\
\hline $\begin{array}{l}\text { 2. Construct/improve } \\
\text { roads to/from Phase I } \\
\text { Site. Identify } \\
\text { interface points'tic- } \\
\text { ins to roads. }\end{array}$ & $\begin{array}{l}\text { 2. Construct road } \\
\text { to/from interim } \\
\text { ILAW storage site. } \\
\text { Identify road } \\
\text { interface point/tie- } \\
\text { in. Identify all } \\
\text { special road criteria } \\
\text { for shielded } \\
\text { container transport } \\
\text { vehicles. }\end{array}$ & $\begin{array}{l}\text { 2. Gain acceptance of } \\
\text { proposed transfer } \\
\text { line routing } \\
\text { between AN/AZ } \\
\text { and AP Tank } \\
\text { Farms. Negotiate } \\
\text { closure of portion } \\
\text { of Canton Ave. } \\
\text { Identify alignment } \\
\text { criteria for PC Loop } \\
\text { Road. }\end{array}$ & $\begin{array}{l}\text { 2. Identify all special } \\
\text { road criteria for } \\
\text { shielded container } \\
\text { transport vehicles. }\end{array}$ & $\begin{array}{l}\text { 2. Identify all special } \\
\text { road criteria for } \\
\text { shielded container } \\
\text { transport vehicles. }\end{array}$ \\
\hline $\begin{array}{l}\text { 3. Evaluate/identify all } \\
\text { impacts to } 200 \text {-East } \\
\text { Area utilities due to } \\
\text { increases in demand } \\
\text { - created by project } \\
\text { and the PC(s); i.e. } \\
\text { raw and potable } \\
\text { water, electricity, etc. }\end{array}$ & $\begin{array}{l}\text { 3. Evaluate/identify all } \\
\text { impacts to } 200 \text {-East } \\
\text { Area utilities due to } \\
\text { increases in } \\
\text { demand created by } \\
\text { project, i.e. raw } \\
\text { and potable water, } \\
\text { electricity, etc. }\end{array}$ & $\begin{array}{l}\text { 3. Evaluate/identify all } \\
\text { impacts to } 200 \text {-East } \\
\text { Area utilities due to } \\
\text { increases in } \\
\text { demand created by } \\
\text { project i.e. raw } \\
\text { and potable water, } \\
\text { electricity, etc. }\end{array}$ & $\begin{array}{l}\text { 3. Evaluate/identify } \\
\text { all impacts to } \\
\text { 200-East Area } \\
\text { utilities due to } \\
\text { increases in } \\
\text { demand created by } \\
\text { project; i.e. raw } \\
\text { and potable water, } \\
\text { electricity, etc. }\end{array}$ & $\begin{array}{l}\text { 3. Evaluate/identify } \\
\text { all impacts to } \\
200 \text {-East Area } \\
\text { utilities due to } \\
\text { increases in } \\
\text { demand created by } \\
\text { project, i.e. raw } \\
\text { and potable water, } \\
\text { electricity, etc. }\end{array}$ \\
\hline $\begin{array}{l}\text { 4. Extend 200-East } \\
\text { Area raw and potable } \\
\text { water distribution } \\
\text { system into Phase I } \\
\text { site. Provide } \\
\text { interface } \\
\text { points/tie-ins. }\end{array}$ & $\begin{array}{l}\text { 4. Extend 200-East } \\
\text { Area raw water } \\
\text { distribution system } \\
\text { into Waste Vauit } \\
\text { site. Identify } \\
\text { interface points/tie- } \\
\text { ins to W-519 water } \\
\text { distribution system. }\end{array}$ & & & \\
\hline $\begin{array}{l}\text { 5. Relocate/replace } \\
\text { structures and } \\
\text { utilities displaced by } \\
\text { Phase I development } \\
\text { that have need for } \\
\text { continued use (i.e., } \\
\text { trailer offices, fences, } \\
\text { sanitary sewer, light } \\
\text { poles, water lines, } \\
\text { roads, etc.). }\end{array}$ & $\begin{array}{l}\text { 5. Utilize former } \\
\text { Grout Facility } \\
\text { complex as much } \\
\text { as is feasible. } \\
\text { Identify utilities' } \\
\text { structures needed. }\end{array}$ & & 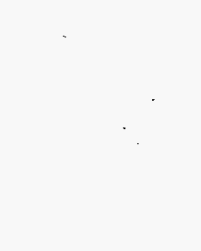 & \\
\hline
\end{tabular}


HNF-2588, Rev. 0

\subsection{Applicable Source/Reference Documents}

Scope and source information on the various projects is available in the references listed below.

HNF-1938, 1997, Summary Conceptual Design Report for Tank Waste Remediation System Privatization Phase I Infrastructure Support, Project W-519, Rev. 0, Fluor Daniel Northwest, Richland, Washington.

HNF-1975, 1998, Conceptual Design Report for Immobilized Low-Activity Waste Interim Storage Facility (Phase I) Project W-465, Rev. 1, Fluor Daniel Northwest, Richland, WA.

HNF-2211, 1998, Design Requirements Document Project W-520 Immobilized Low Activity Waste Disposal, Draft, Numatec Hanford Corporation, Richland, Washington.

HNF-2298, 1998, Conceptual Design Report, Immobilized High Level Waste Interim Storage Facility (Phase I), Rev. 0, Fluor Daniel Northwest, Richland, Washington.

HNF-2500, 1998, Waste Transfer Alternative Piping System Design, Draft, Numatec Hanford Corporation, Richland, Washington.

HNF-SD-W314-RPT-003, 1997, Tank Farm Restoration and Safe Operations, Project W-314, Upgrade Summary Report (USSR), Rev. 0, Numatec Hanford Corporation, Richland, WA.

HNF-SD-W465-DRD-001, 1997, Design Requirements Document for Immobilized Low Activity Waste Interim Storage, Rev. 0, SGN Eurisys Services Corporation, Richland, Washington.

HNF-SD-WM-DRD-011, 1997, Design Requirements Document for the Phase I Privatization Electrical Power System, Rev. 1, Numatec Hanford Corporation, Richland, Washington.

HNF-SD-WM-DRD-013, 1997, Design Requirements Document for the TWRS Privatization Phase I Site Development, Rev. 1, Fluor Daniel Northwest, Richland, Washington.

WHC-SD-WM-DRD-012, 1996, Design Requirements Document for the Interim Store Phase I Solidified High Level Waste, Rev. 0, Westinghouse Hanford Corporation, Richland, Washington.

WHC-SD-WM-DRD-014, 1996, Design Requirements Document Privatization Phase I Liquid Effluent Transfer Systems, Rev. 0, ICF Kaiser Hanford Co., Richland, Washington.

WHC-SD-WM-DRD-015, 1996, Design Requirements Document for the TWRS Privatization Phase I Raw and Potable Water Service, Rev. 0, ICF Kaiser Hanford Co., Richland, Washington. 
HNF-2588, Rev. 0

\subsection{Interfaces and Requirements}

This section first identifies where the other projects interface with Project W-519, then establishes the requirements and responsibilities associated with the various interfaces.

The main elements of the various projects that require interfacing and coordination with Project W-519 are:

- Project W-465 will modify the Waste Vaults that exist within the former Grout Disposal Compound for temporary storage, and possible future disposal, of Immobilized Low Activity Waste (ILAW) and will utilize the existing Grout Facility office trailer and control room complex for operations staff. Interfaces with elements of Project W-519 are required for land use, road access, raw water for fire suppression and construction activities, ground water monitoring wells, and potentially sanitary sewer. Electrical power is obtained from the 200 Area distribution grid employing existing transmission lines and transformers, and no direct interfaces with W-519 electrical systems are required other than the shared demand on the 200-East Area infrastructure. Similarly, potable water is supplied to the office trailer complex via an existing pipeline tied to the existing distribution system and there are no interfaces with elements provided by W-519.

- Project W-314 has been established to provide upgrades in the areas of instrumentation and control, tank ventilation, waste transfer, and electrical distribution for existing mixed waste tank farm facilities at Hanford. Though Project W-211, Initial Double-Shell Tank Retrieval Systems, is currently chartered with providing High-Level Waste (HLW) transfer lines between the various tank farms and the PC(s), through a cost savings initiative several new HLW transfer lines between the AN and AZ Tank Farms and the AP Tank Farm are being proposed as part of Project W-314. Proposed routing requires the construction of a 5 to 7 meter high embankment that crosses Canton Avenue just north of the 207-A Basins at the same location PC Loop Road intersects Canton Avenue. Land use, road access, and site development interfaces with elements of Project W-519 are required should the proposed routing be implemented. There are no other interfaces other than the shared demand on the 200-East Area infrastructure (water, electricity, etc.).

- Project W-464 will modify vaults 2 and 3 at the Canister Storage Building (CSB), located on the west side of the 200-East Area (about $2.6 \mathrm{~km}$ west of the former Grout Disposal Compound), for interim storage of immobilized high level waste (IHLW). The shipment of IHLW between the PC's HLW vitrification facility and the storage vaults will be by shielded container transporter over intra-area and inter-area roads. Shared demand on the 200-East Area infrastructure (water, 
HNF-2588, Rev. 0

electricity, roads, etc.) and road design criteria for the shielded container transporter are the only interfaces with elements of Project W-519.

- Project W-520 will construct Immobilized Low-Activity Waste (ILAW) disposal vaults in an area east of Baltimore Avenue (about $1.6 \mathrm{~km}$ west of the former Grout Disposal Compound). The shipment of ILAW between the PC's treatment facilities and the ILAW disposal area will be by shielded container truck/trailer over intra-area roads. Shared demand on the 200-East Area infrastructure (water, electricity, roads, etc.) and road design criteria for the shielded container transporter are the only interfaces with elements of Project W-519.

\subsection{Land Use (Site) Allocation and Scheduling of Shared/Interfacing Areas}

In order to perform its function, each project has need for an amount of land for placement of facilities and for temporary use during construction. Through identifying the extent of land use by a given project, scheduling, and the coordination of activities, areas may be shared.

\subsubsection{Land Use Requirements}

The former Grout Disposal Compound has been selected as the site for the construction of the TWRS Privatization Phase I facilities. The compound is to be divided among two competing PC(s), with each PC being leased a parcel of at least 22 hectares $(55$ acres) each for the construction and operation of treatment facilities. Parcel layout, as well as the necessary utility and road corridors and waste transfer/feed corridors from existing 200-East Area facilities to the PC parcels, are identified on sketch ES-W505-C01 in HNF-1938, Appendix L.

3.1.1.1 Project W-465 Land Use Interfaces - The Waste Vaults that exist within the excavated depression in the western most portion of the former Grout Disposal Compound will be modified for the interim storage and possible disposal of ILAW. Project W-465 will also utilize the existing Grout Facility office trailers (MO-282, MO-283, MO-997, and MO-674) and the existing Grout Facility Control Room (Building 234-G4) for operations. (Office trailer MO-284 is currently being used by Tank Farm operations.) Facility layout and land use needs for access into the excavation are identified on sketch ES-W465-C2 in HNF-1975, Appendix M.

Table 2 summarizes land allocations and related interface responsibilities between Projects W-519 and W-465. 
HNF-2588, Rev. 0

\begin{tabular}{|c|c|c|c|c|}
\hline & \multicolumn{2}{|c|}{ Project Requirements } & \multicolumn{2}{|c|}{ Interface Responsibilities } \\
\hline & Project W-519 & Project W-465 & Project W-519 & Project W-465 \\
\hline 1 & $\begin{array}{l}\text { Prepare transfer/feed } \\
\text { corridors in preparation } \\
\text { for } P C \text { construction by } \\
\text { removing above ground } \\
\text { obstructions. Existing } \\
\text { change room must be } \\
\text { removed/relocated. }\end{array}$ & $\begin{array}{l}\text { Utilize former Grout } \\
\text { Complex facilities as } \\
\text { much as is feasible. } \\
\text { Provide change room. }\end{array}$ & $\begin{array}{l}\text { Remove/relocate } \\
\text { existing change room. }\end{array}$ & $\begin{array}{l}\text { Remodel one of the } \\
\text { remaining office trailers } \\
\text { (MO-282, MO-283, } \\
\text { MO-997, or MO-674) into } \\
\text { a change room if existing } \\
\text { change room cannot be } \\
\text { relocated economically. }\end{array}$ \\
\hline 2 & $\begin{array}{l}\text { Prepare } 18 \mathrm{~m}(60 \mathrm{ft}) \\
\text { min. wide transfer/feed } \\
\text { corridors in preparation } \\
\text { for PC construction. }\end{array}$ & $\begin{array}{l}\text { Construct gentle ramp into } \\
\text { Waste Vault excavation } \\
\text { for shielded container } \\
\text { transfer vehicle access. }\end{array}$ & $\begin{array}{l}\text { Assure exist storm } \\
\text { water control berm } \\
\text { around perimeter of } \\
\text { excavation remains } \\
\text { intact. }\end{array}$ & $\begin{array}{l}\text { Construct ramp without } \\
\text { expanding Waste Vault } \\
\text { excavation. }\end{array}$ \\
\hline 3 & $\begin{array}{l}\text { Identify underground } \\
\text { features that may } \\
\text { obstruct construction of } \\
\text { transfer/feed lines. PC } \\
\text { will remove interfering } \\
\text { below grade } \\
\text { obstructions during } \\
\text { construction. Existing } \\
\text { septic system may be } \\
\text { destroyed as a result. }\end{array}$ & $\begin{array}{l}\text { Utilize former Grout } \\
\text { Complex facilities as } \\
\text { much as is feasible, } \\
\text { including existing sanitary } \\
\text { sewer treatment system. } \\
\text { Provide electrical power, } \\
\text { communications, etc. from } \\
\text { control room to Waste } \\
\text { Vaults. }\end{array}$ & $\begin{array}{l}\text { Relocate/replace } \\
\text { existing utilities } \\
\text { displaced by Phase I } \\
\text { development where } \\
\text { continued use is made } \\
\text { evident. Construct } \\
\text { replacement septic } \\
\text { system if existing is to } \\
\text { be destroyed by PC. }\end{array}$ & $\begin{array}{l}\text { Coordinate location of } \\
\text { duct bank with PC's } \\
\text { transfer feed line or place } \\
\text { services overhead. } \\
\text { Identify occupancy factors } \\
\text { for sizing septic system. }\end{array}$ \\
\hline 4 & $\begin{array}{l}\text { Identify existing } \\
\text { groundwater monitoring } \\
\text { wells potentially } \\
\text { impacted by PC } \\
\text { construction activities. }\end{array}$ & $\begin{array}{l}\text { Utilize former Grout } \\
\text { Complex facilities as } \\
\text { much as is feasible. } \\
\text { Should complex be used } \\
\text { for IIAW disposal, } \\
\text { provide groundwater } \\
\text { monitoring wells. }\end{array}$ & $\begin{array}{l}\text { Replace any } \\
\text { groundwater monitoring } \\
\text { wells that have a future } \\
\text { need that are removed in } \\
\text { the preparation for, or } \\
\text { during PC Construction. }\end{array}$ & $\begin{array}{l}\text { Identify those existing } \\
\text { groundwater monitoring } \\
\text { wells that have a future } \\
\text { need if the Waste Vaults } \\
\text { are employed for ILAW } \\
\text { disposal. }\end{array}$ \\
\hline
\end{tabular}

Construction work under Project W-465 will be confined within the bounds of the existing Waste Vault excavation with the exception of the access road, raw water line for fire suppression systems and hydrants, and electrical/instrumentation/communication conduits from the control room to the Waste Vaults. Project W-465 is responsible to coordinate with the respective PC the design, as well as construction, of all crossings of the transfer/feed corridors by any conduits, water lines, and/or roads. To assure adequate space for the PC to construct transfer/feed lines, the existing Waste Vault excavation will not be expanded on the north, west, and south sides as 
HNF-2588, Rev. 0

the corridors established for the construction of the transfer/feed pipelines bound the Waste Vault excavation at those locations.

The corridors for the transfer/feed pipelines also bound the Grout Facility Office Complex on the south and east. All above grade structures within the corridors will be removed and/or relocated by project W-519, and include the change room, power and light poles, and fencing. Project W-465 will convert one of the remaining existing office trailers into a change room as a replacement for the change room removed by W-519.

Several active ground water monitoring wells, constructed for the Grout Disposal Program, exist along the southern and western edges of the Waste Vault excavation and within the corridors established for the PC(s) to construct transfer/feed pipelines. The wells are seldom sampled but may have importance later on in supporting a RCRA groundwater monitoring program should the Waste Vaults be employed for permanent disposal of ILAW. Currently, none of the wells are planned for closure as they are situated along the edges of the corridors and it's anticipated the wells can be avoided during transfer/feed line construction.

The existing 2607-E10 sanitary drain field that serves the office trailer complex lies within the transfer/feed line corridor and may have to be abandoned. If necessary, a replacement drain field will be constructed by Project W-519 at a location to be determined (TBD), along with the necessary sewage pumps and pressure main (see 3.4.1).

Once construction of the below grade transfer/feed pipelines are complete, the transfer/feed corridors may be returned to limited use by adjoining facilities.

3.1.1.2 Project W-314 Land Use Interfaces - Currently under review is a proposed change to the Project W-314 baseline that will add several High-Level Waste (HLW) transfer lines between the AN and AZ Tank Farms and the AP Tank Farm (reference HNF-2500). The proposed routing requires the construction of a 5 to 7 meter high embankment that crosses Canton Avenue just east of the 241-AX Tank Farm and extends around the north end of the 207-A Basins. The embankment will effectively block off Canton Avenue just north of the location where Project W-519 is to construct the PC Loop Road/Canton Avenue intersection.

Should Project W-314 opt to employ the routing that's being proposed, the west end of north PC Loop road will be redirected to run parallel with the pipeline embankment to intersect Canton Avenue approximately 120 meters north of the location identified on sketch ES-W505-C01 in appendix $\mathrm{L}$ of the W-519 CDR (HNF-1938).

The raw and potable water line tie-in points, currently planned for Project W-519, will be affected as the points will lie beneath the embankment being proposed by Project W-314. The tie-in points 
HNF-2588, Rev. 0

would be relocated by Project W-519 to north of the current location to a point just beyond the toe of the Project W-314 embankment.

The tie-in for the non-radioactive, non-hazardous effluent pipeline, to be constructed as part of Project W-519, may also require relocation should Project W-314 opt to employ the pipeline embankment. As the non-radioactive, non-hazardous effluent pipeline drains by gravity, has a very flat slope, and threads over and under several existing pipelines, a relocation of the tie-in point may not be practical. As the schedule for Project W-314 construction (see Figure 1) is earlier than for Project W-519, Project W-314 may be required to place an encasement under the embankment for the later installation of the non-radioactive, non-hazardous effluent pipeline.

The radioactive, hazardous effluent pipeline, to be constructed as part of Project W-519, will require minor realignment should Project W-314 opt to employ the pipeline embankment. The radioactive, hazardous effluent pipeline will be rerouted as required to run parallel with the realigned PC Loop Road until it turns north to run parallel with the PC 5000 line serving the 242-A Evaporator.

\subsubsection{Construction/Operation Schedule}

A time line schedule/chart is shown in Figure 1. The design and construction periods currently planned for W-314, W-464, W-465, W-519, W-520, and the Privatization Contractors are indicated.

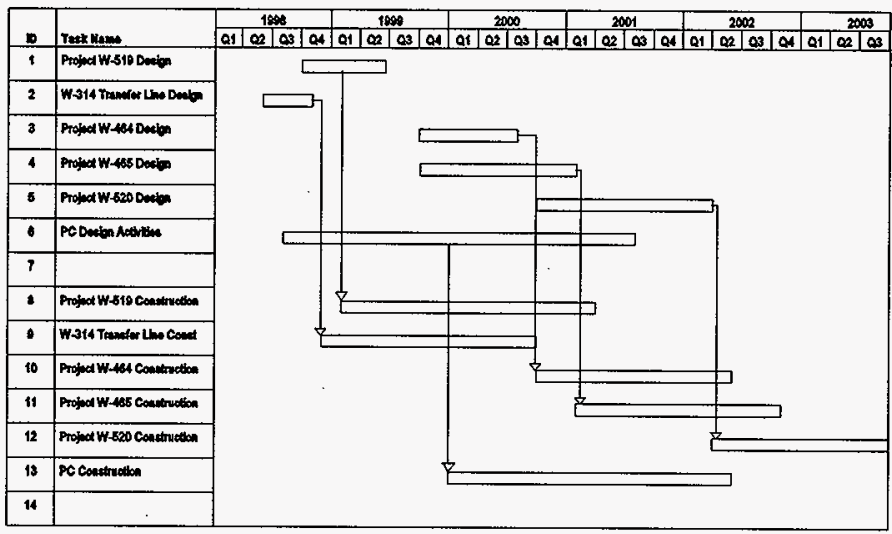

Figure 1. Time Line Schedule 
HNF-2588, Rev. 0

3.1.2.1 Project $W-465$ Schedule Interfaces - The $P C(s)$ will be constructing transfer/feed pipelines within the corridors that bound the Waste Vault excavation during the same time frame Project W-465 will be constructing several services that cross through the corridors into the Waste Vault area. Coordination and scheduling of activities will be required to assure that no interferences are created and that no new elements (i.e., freshly constructed roads) will have to be removed shortly after completion. The overall goal will be to minimize impacts to Privatization Contractor activities. There are three items that require particular attention in the scheduling of construction activities:

- 1) A duct bank will be constructed across the transfer/feed corridor from the former Grout Control Room to the Waste Vaults for power and communication distribution.

- 2) The raw water main for serving Waste Vault fire suppression systems will cross the corridors at two locations. (See 3.3.3.1 for proposed change to the route identified in the W-465 CDR.)

- 3) The main access road into the Waste Vault area must cross over the transfer/feed lines serving the $\mathrm{PC}(\mathrm{s})$ at two locations.

The responsibility of coordinating construction activities with the PC(s) will be that of Project W-465.

3.1.2.2 Project W-314 Schedule Interfaces - Should the proposed routing of the AP/AN transfer line be approved, construction of the transfer line will occur simultaneous to the construction of PC Loop Road and the tie-ins to raw water, potable water, non-radioactive effluent, and radioactive effluent lines by Project W-519. Tie-in locations of each of these services will probably require modification and some services may have to cross under the transfer line. Both projects have the responsibility to maintain close coordination between the elements of design and construction scheduling.

3.1.2.3 Project W-464 Schedule Interfaces - Construction activities at the IHLW Storage Facility will commence while the PC(s) are midway through construction. Due to the distance separating the Privatization Site and the IHLW Storage Facility, other than the impacts caused to the Hanford Site inter-area road system by the increase in traffic, there are no interface items dealing with construction schedule issues.

3.1.2.4 Project W-520 Schedule Interfaces - Construction activities at the ILAW Disposal Facility will commence as the $\mathrm{PC}(\mathrm{s})$ are nearing completion of their facilities. There are no construction activities requiring coordination other than possible traffic impacts to the Hanford Site road system. 
HNF-2588, Rev. 0

\subsection{Roads}

In order to perform it's function, each project has the need for road access. During construction, traffic volumes may increase substantially leading to highway congestion and unsafe conditions. Should traffic volumes prove unacceptable, some traffic could be assigned specific routes of travel, e.g., via Route 11A with entry into the 200-East Area using north Canton Avenue.

In the process of providing access into the Phase I site, Project W-519 will upgrade three intersections, including major upgrades to the Canton Avenue / Route 4 South intersection, widen and overlay over $2300 \mathrm{~m}$ (7,546 ft) of existing roadway, and construct about $1800 \mathrm{~m}(5,906 \mathrm{ft})$ of new roadway (see sketch ES-W505-C01, Appendix L of HNF-1938).

\subsubsection{Road Requirements}

All roads will be designed in accordance with the American Association of State Highway and Transportation Officials (AASHTO) Policy on Geometric Design of Highways and Streets. Tuming radii and road cross section widths at intersections and curves will be as required for large, shielded container bearing tractor/trailer rigs. Wheel loading design shall meet the Washington State Department of Transportation HS20 standard.

3.2.1.1 Project W-465 Road Interfaces - Large tractor/trailer vehicles will transport ILAW within shielded containers from the PC treatment facilities to the interim storage units (modified Waste Vaults) provided under Project W-465. Transport will be over intra-area roads provided by Projects W-519 and W-465. The interface between the two projects for roads will occur at the edge of PC Loop Road at approximately N 136121, E 576180. All road construction south of the interface point that leads to the Waste Vaults is the responsibility of Project W-465 (See 3.1.2.1). Construction of PC Loop Road will be the responsibility of Project W-519. Project responsibilities for the construction of intra-area roads south of the Waste Vaults and between AP Tank Farm and the PC facilities has not been identified (see 4.2). Minimum turn radii and road width of Project W-519 and Project W-465 roads shall be as required for standard dimension truck/trailer rigs meeting Department of Transportation (DOT) standards for vehicles of less than 36.3 metric tons ( 80,000 pounds) Gross Vehicle Weight (vehicles provided by Project W-465).

To maintain access to the W-465 Office Trailer complex (formerly the Grout Facility Office complex) during construction of the transfer/feed lines by the $\mathrm{PC}(\mathrm{s})$, the northern portion of Grout Drive will be converted from a one way road to bi-directional. The southern portion of Grout Drive is within the corridor identified for the PC(s) to construct transfer/feed pipelines and will most likely be demolished.

3.2.1.2 Project W-314 Road Interfaces - Project W-314 is currently investigating the routing of a High-Level Waste (HLW) transfer line from AN Tank Farm to AP Tank Farm that will modify 
HNF-2588, Rev. 0

the alignment and/or profile of the northwestern end of PC Loop Road over that currently planned by Project W-519.

3.2.1.3 Project W-464 Road Interfaces - Large tractor/trailer vehicles will transport IHLW within shielded containers from the PC treatment facilities to the interim storage units at the Canister Storage Building (CSB) provided under Project W-464. Transport will be over existing inter-area roads (Route 4) and new and upgraded intra-area roads provided by Project W-519. Project W-519 is responsible for the upgrade of the Canton Avenue / Route 4 intersection, of Canton Avenue from Route 4 to South PC Loop Road, and PC Loop Road. It is not anticipated that Route 4 from Canton Avenue to the entrance road to the CSB will require any improvements. Other than providing for large turning radius vehicles in the design of the intraarea roads, there are no interfaces. Though the Gross Vehicle Weight (GVW) of the transport vehicle is expected to be 50 metric tons (110,000 pounds), minimum turn radii and road width of Project W-519 roads shall be as required for standard dimension truck/trailer rigs meeting Department of Transportation (DOT) standards for vehicles of less than 36.3 metric tons ( 80,000 pounds) GVW (vehicles provided by Project W-464).

3.2.1.4 Project W-520 Road Interfaces - Large tractor/trailer vehicles will transport ILAW within shielded containers from the PC treatment facilities to the disposal units provided under Project W-520. Transport will be over existing upgraded intra-area roads and new roads provided by Projects W-519 and W-520. Project W-520 is responsible for the upgrade of First Street from Canton Avenue to the W-520 disposal units. Project W-519 is responsible for the upgrade of Canton Avenue from Route 4 to South PC Loop Road, and PC Loop Road. Other than providing for large turning radius vehicles in the design of the roads, there are no interfaces. Minimum turn radii and road width of Project W-519 and Project W-520 roads shall be as required for standard dimension truck/trailer rigs meeting Department of Transportation (DOT) standards for vehicles of less than 36.3 metric tons ( 80,000 pounds) Gross Vehicle Weight (vehicles provided by Projects W-520 and W-465).

\subsection{Raw Water}

In order to perform it's function, each project has the need for raw water for construction purposes (such as dust control) and for fire suppression water. The Privatization Contractors (Project W-519) will also use raw water for a process water supply.

Each project is responsible to perform an evaluation of the effects the elements of that project place on the 200-East Area raw water distribution system. All deleterious effects are to be resolved by the respective project. 
HNF-2588, Rev. 0

\subsubsection{Construction Water}

In the spring of 1999, Project W-519 will repair and return to service an existing construction water riser that is situated south of the 216-A-6 Crib. Project W-519 will employ the riser from spring 1999 to early winter 1999 to provide water for dust control and soil compaction activities. The riser may also be used by the Privatization Contractors during this same period. In the late fall 1999 construction of the raw water distribution system expansion will be complete and construction water can be obtained from one of several fire hydrants distributed throughout the former grout compound.

3.3.1.1 Project W-465 Construction Water Interface - Site preparation activities are scheduled to begin in the fall of 2000 and completed by spring 2001 . Construction water will be obtained from a fire hydrant provide by Project W-519 and located approximately 400 meters northeast of the Waste Vaults.

3.3.1.2 Project W-314 Construction Water Interface - Should the proposed routing for the waste transfer line be implemented it is assumed that construction will begin the fall of 1998 and be completed by spring 2000 . Construction water for dust control and soil compaction will be obtained from one of the existing fire hydrants near the AX and AN tank farms. Use of the existing riser south of the 216-A-6 Crib is possible, but unlikely, given the distance from the construction site.

3.3.1.3 Project W-464 Construction Water Interface - No interfaces other than sharing the existing 200 Area raw water distribution system.

3.3.1.4 Project W-520 Construction Water Interface - No interfaces other than sharing the existing 200 Area raw water distribution system.

\subsubsection{Process Water}

Only the Privatization Contractors (Project W-519) will utilize the 200 East Area raw water distribution system for supplying water for process needs. There are no other interfaces other than the sharing of the existing 200 Area raw water distribution system.

\subsubsection{Fire Suppression Water}

Each project has the need for raw water for fire suppression activities. Site wide criteria (RLID 5480.7) establishes the minimum distribution pipe size as DN300 (12 inch), requires alternate flow paths back to the source of water (the 284-E reservoir), and requires the distribution system to have the ability to supply up to 9450 liters per minute (2,500 gpm) during a 
HNF-2588, Rev. 0

design basis fire (DBF). Due to the low probability of simultaneous occurrence, the distribution system need only to respond to one DBF at any given time.

In extending the existing 200 East Area raw water distribution into the former Grout Compound, the distribution system extension and improvements provided by Project W-519 will comply with the requirements of RLID 5480.7 .

3.3.3.1 Project W-465 Fire Suppression Water Interface - Fire suppression within the modified Waste Vaults will be provided by dry pipe sprinkler systems and supplemented by fire hydrants strategically located about the Waste Vault excavation. Fire suppression water will be supplied to the Waste Vault area by tying into the raw water distribution system extended by Project W-519 at two locations. Project W-519 will provide a capped DN300 mechanical joint connection at the following approximate coordinates:

- $\quad \mathrm{N} 136115$, E 576170

and

- $\quad \mathrm{N} 135460, \mathrm{E} 576440$

The locations noted differ somewhat from the locations noted on sketch ES-W465-C2 in the W-465 CDR. The first interface point has been relocated on the west side of the access road into the Waste Vault excavation to provide separation from liquid effluent lines serving the Privatization Contractors. The second location has been relocated from 530 meters (1,740 feet) west of the Waste Vault excavation to 450 meters (1480 feet) southeast of the excavation to avoid constructing the water line through the corridors set aside for the Privatization Contractors to construct waste transfer/feed pipelines.

3.3.3.2 Project W-314 Fire Suppression Water Interface - No interfaces other than sharing the existing 200 Area raw water distribution system.

3.3.3.3 Project W-464 Fire Suppression Water Interface - No interfaces other than sharing the existing 200 Area raw water distribution system.

3.3.3.4 Project W-520 Fire Suppression Water Interface - No interfaces other than sharing the existing 200 Area raw water distribution system. 
HNF-2588, Rev. 0

\subsection{Electrical Power}

In order to perform it's function, each project has the need for electrical power for both construction activities and operations. Other than the shared demand on the 200-East Area infrastructure there are no direct interfaces dealing with electrical power between Project W-519 and Projects W-314, W-464, W-465, and W-520.

Each project has the responsibility to identify and evaluate the impacts placed on the 200-East Area electrical power distribution system by it and any validated project. The evaluation shall include impacts to any related documentation. Each project will take the actions necessary to resolve any adverse impacts. Should it appear cost effective, Project W-519 scope may be modified to assist in the resolution of impacts. Any changes in scope will be through a formal request, evaluated, and implemented through the change request process.

\subsection{Sanitary Sewage Collection, Treatment, and Disposal}

Project W-465 will utilize the existing Grout Facility office trailer and control room complex for operations staff. The existing Sanitary Sewage treatment facility (Facility number 2607-E10) serving the former grout facility office trailer complex may be displaced as part of the installation of transfer/feed pipelines by the PC assigned the northern Phase I parcel.

\subsubsection{Sanitary Sewer Interface}

Should it be necessary, Project W-519 will replace the 2607-E10 sanitary sewer system at a location yet to be determined and provide the collection system necessary to convey sanitary sewage from the existing complex to the replacement treatment facility. The replacement system will adhere to Washington State Department of Health requirements. 
HNF-2588, Rev. 0

\subsection{Issues}

The following section identifies issues on the interfaces and the efforts or study(ies) required to resolve the issues.

\subsection{Proposed AN/AZ to AP Transfer Line Route}

In a cost savings initiative, a proposal is being forwarded within Project W-314 that will route HLW transfer lines directly from the AN/AZ Tank Farms to the AP Tank Farm through an area north and east of the 207-A Basins. The route will require a 5 to 7 meter high embankment to be constructed across Canton Avenue northwest of the 207-A Basins. Implementation of the proposal will require modification to the baselines of Project W-211, W-314, and W-519.

Assigned to: Project W-314

Schedule Date: June 30, 1998

Direction must be given by DOE-RL, through appropriate change control, as whether or not to proceed with the proposal.

\section{4,2 Intra-area road between AP Tank Farm and PC Facilities}

Project responsibilities for the construction of intra-area roads between AP Tank Farm and the PC facilities has not been established. After the PC(s) complete construction of their transfer/feed pipelines intra-area roads should be constructed within the corridor that would provide a direct route from the PC's treatment facilities to their operations at the AP Tank Farm. Responsibilities for providing this road have not been identified.

Assigned to: Project W-519

Schedule Date: July 31, 1998

Direction must be given by DOE-RL as whether to initiate a change in one projects scope, direct that the construction of the roadways are the responsibility of the $\mathrm{PC}(\mathrm{s})$, or to initiate a new project. 